\title{
C-Aryl Glycosides via Tandem Intramolecular Benzyne-Furan Cycloadditions. Total Synthesis of Vineomycinone $B_{2}$ Methyl Ester
}

\author{
Chi-Li Chen, Steven M. Sparks ${ }^{\dagger}$, and Stephen F. Martin \\ Department of Chemistry and Biochemistry, The University of Texas, Austin, Texas
}

The vineomycins are a group of glycosidic antibiotics that were isolated from a culture of Streptomyces matensis vineus and found to be active against Gram-positive bacteria and sarcoma-180 solid tumors in mice. ${ }^{1}$ Acid-catalyzed methanolysis of vineomycin $\mathrm{B}_{2}$ furnished the aglycone vineomycinone $B_{2}$ methyl ester (1). Bearing an olivose residue appended to one ring of the anthrarufin core, $\mathbf{1}$ is a representative member of the $C$-aryl glycoside family of natural products. ${ }^{2} \mathrm{~A} 3(R)$-hydroxyisovaleryl side chain adorns the opposite side of the core making vineomycinone $B_{2}$ methyl ester an intriguing target of modest complexity. Indeed, the structure of 1 coupled with its potential anticancer activity has rendered vineomycinone $\mathrm{B}_{2}$ methyl ester the object of a number of investigations, four of which have culminated in total syntheses. ${ }^{3}$ Despite these successes, there remains ample opportunity for the development of new chemistries.

In the context of an interest in $C$-aryl glycoside antibiotics, we recently developed a general entry to the four major classes of this family of natural products. ${ }^{4}$ The strategy features the ring opening of cycloadducts that are obtained from Diels-Alder cycloadditions of substituted benzynes with glycosyl furans. Having established the basic elements of the approach, we turned to the task of applying it to the syntheses of naturally occurring $C$-aryl glycosides as an obligatory test of its true utility. We now report the application of this methodology to a facile synthesis of vineomycinone $B_{2}$ methyl ester (1).

The two substituents on $\mathbf{1}$ are unsymmetrically positioned on the anthrarufin nucleus. Hence, the major challenge is controlling the regioselectivity in the Diels-Alder reactions that would simultaneously assemble the aromatic framework and introduce the carbohydrate and aliphatic residues. We had previously developed a practical solution to this problem by using disposable silicon tethers to link the reacting benzyne and furan moieties. ${ }^{4 \mathrm{~d}}$ Based upon that advance, a novel and highly convergent strategy eventuated for preparing 1 (Figure 1). The synthesis features tandem intramolecular benzyne-furan cycloadditions originating from the key intermediate 3 to generate the bisoxabenzonorbornadiene 2 in a single operation. ${ }^{5}$ The conversion of $\mathbf{2}$ into 1 requires cleavage of the silicon tethers, ring opening of the bisoxabenzonorbornene core, global removal of the oxygen protecting groups, and adjustment of the oxidation level in the alkyl side chain. The cycloaddition precursor $\mathbf{3}$ would be prepared by iterative Mitsunobu coupling of tetrabromohydroquinone (5) with the silicon-substituted furans $\mathbf{4}$ and $\mathbf{6}$, both of which would be derived from readily available starting materials.

E-mail: sfmartin@mail.utexas.edu.

†Present Address: GlaxoSmithKline, 5 Moore Drive, Research Triangle Park, NC 27709.

Supporting Information Available: Experimental procedures for 2-4, 9, 17, and 19 as well as spectral data and copies of ${ }^{1} \mathrm{H}$ NMR spectra for all new compounds together with copies of ${ }^{1} \mathrm{H}$ NMR spectra of synthetic and authentic 1 and a tabular comparison of ${ }^{13} \mathrm{C}$ NMR data for synthetic and authentic 1. This material is available free of charge via the Internet at http://pubs.acs.org. 
Preparation of 4 commenced with adding 3-lithiofuran to the known lactone $7^{4 c}$ to afford a mixture of lactols, which were in equilibrium with the open chain keto-alcohol (Scheme 1). This mixture was treated directly with ethanolic- $\mathrm{HCl}$ to furnish an intermediate ethyl acetal that was stereoselectively reduced upon heating with $\mathrm{NaCNBH}_{3}$ in ethanolic- $\mathrm{HCl}$ to form glycosylfuran 8 in $80 \%$ overall yield. ${ }^{6}$ Regioselective metallation ${ }^{4 d, 7}$ of $\mathbf{8}$ followed by trapping with chlorodimethylvinylsilane furnished the vinyl silane $\mathbf{9}$, which was subjected to hydroboration/oxidation ${ }^{8}$ to deliver furan 4 in $66 \%$ yield over two steps.

Turning to the synthesis of furan 6, 3-methyl-3-butenol was first protected as its PMP ether and subjected to Sharpless asymmetric dihydroxylation conditions to afford diol $\mathbf{1 1}$ in $93 \%$ yield over two steps (96\% ee) (Scheme 2). ${ }^{9}$ The primary tosylate derived from 11 was cyclized by deprotonation with $n$-BuLi to give an intermediate epoxide that underwent facile opening in situ with 3-lithiofuran in the presence of $\mathrm{BF}_{3} \cdot \mathrm{OEt}_{2}$ to provide the tertiary alcohol 12 in $76 \%$ overall yield. $O$-Benzylation of the hydroxyl group in $\mathbf{1 2}$ gave 13, regioselective bromination of which with NBS furnished bromide 14 in $86 \%$ yield over two steps. ${ }^{10}$ The furyl bromide was subjected to metal-halogen exchange, and the resulting anion was trapped with chlorodimethylvinylsilane to afford the vinylsilane $\mathbf{1 5}$ in $87 \%$ yield. Subsequent hydroboration and oxidation of the vinyl moiety as before delivered the furan $\mathbf{6}$.

The assembly of $\mathbf{3}$ then proceeded uneventfully (Scheme 3). Alcohol $\mathbf{6}$ and the monoprotected phenol $16^{11}$ underwent Mitsunobu coupling employing DIAD and $\mathrm{PPh}_{3}$ to furnish the aryl ether 17 in $75 \%$ yield. Removal of the silyl protecting group utilizing HF•pyridine in THF released the phenol 18 that was then coupled with furan $\mathbf{4}$ via a second Mitsunobu reaction to deliver 3 in $72 \%$ yield over two steps.

With the Diels-Alder precursor 3 in hand, the stage was set for the pivotal domino benzynefuran cycloaddition. Gratifyingly, dropwise addition of $n$-BuLi ( $0.23 \mathrm{M}, 3.0$ equiv) to a solution of tetrabromide 3 in $\mathrm{Et}_{2} \mathrm{O}$ at $-20{ }^{\circ} \mathrm{C}$ afforded biscycloaddition product 2 in $85 \%$ yield as a mixture of diastereomers (Scheme 4). After some experimentation, we discovered that the bonds between the silicon atoms and the bridgehead carbon atoms in $\mathbf{2}$ were most efficiently cleaved under modified Rickborn ${ }^{12}$ conditions using $\mathrm{KOH}$ in $\mathrm{DMF} / \mathrm{H}_{2} \mathrm{O}$ (10:1). Treatment of the crude mixture thus obtained with hydrochloric acid resulted in the regioselective opening $4 \mathrm{a}-\mathrm{d}_{\text {of }}$ the two bicyclooxaheptene rings, and subsequent air oxidation furnished the anthrarufin 19 in $34 \%$ overall yield together with several unidentified products.

Completion of the synthesis of vineomycinone $\mathrm{B}_{2}$ methyl ester then required removal of the various protecting groups and adjustment of the oxidation level of the aliphatic side chain. The PMP group was thus cleaved under oxidative conditions with CAN to give alcohol 20 in $74 \%$ yield. Subsequent oxidation of alcohol 20 with IBX generated an aldehyde intermediate, which was transformed into acid $\mathbf{2 1}$ in $70 \%$ yield by reaction with $\mathrm{NaClO}_{2}$. Global deprotection of the benzyl groups with $\mathrm{BBr}_{3}$ followed by work-up with methanolic hydrogen chloride provided synthetic vineomycinone $\mathrm{B}_{2}$ methyl ester $(\mathbf{1})$ in $71 \%$ yield. The synthetic material thus obtained gave ${ }^{1} \mathrm{H}$ and ${ }^{13} \mathrm{C}$ NMR spectra identical with an authentic sample.

In summary, a novel and highly convergent synthesis of vineomycinone $\mathrm{B}_{2}$ methyl ester (1) has been completed by a process that required 16 steps, the same length as the shortest previous synthesis of $1,3 b$ in the longest linear sequence. The synthesis features the first application of our strategy for using silicon tethers as disposable linkers to control the regiochemistry in DielsAlder reactions of substituted benzynes and furans. Such constructions enable the rapid assembly of the glycosyl-substituted aromatic cores of complex $C$-aryl glycoside antibiotics from simple starting materials. Other applications of this strategy are in progress and will be reported in due course. 


\section{Supplementary Material}

Refer to Web version on PubMed Central for supplementary material.

\section{Acknowledgment}

We thank the National Institutes of Health (GM 31077), the Robert A. Welch Foundation, Pfizer, Inc., and Merck Research Laboratories for their generous support of this research. We are also grateful to Prof. Marcus A. Tius (University of Hawaii) for providing an authentic sample of vineomycinone B2 methyl ester (1).

\section{References}

1 (a). Omura S, Tanaka H, Oiwa R, Awaya J, Masuma R, Tanaka K. J. Antibiot 1977;30:908. [PubMed: 591459] (b) Imamura N, Kakinuma K, Ikekawa N, Tanaka H, Omura S. J. Antibiot 1981;34:1517. [PubMed: 7319914]

2 (a). Levy, DE.; Tang, C. The Chemistry of C-Glycosides. Elsevier Science; Tarrytown, NY: 1995. (c) Nicotra F. Top. Curr. Chem 1997;187:55. (d) Du Y, Linhardt RJ, Vlahov IR. Tetrahedron 1998;54:9913. (e) Liu L, McKee M, Postema MHD. Curr. Org. Chem 2001;5:1133.For general reviews of C-aryl glycosides, see: Jaramillo C, Knapp S. Synthesis 1994:1.

3 (a). (b) Tius MA, Gomez-Galeno J, Gu XQ, Zaidi JH. J. Am. Chem. Soc 1991;113:5775. (c) Bolitt V, Mioskowski C, Kollah RO, Manna S, Rajapaksa D, Falck JR. J. Am. Chem. Soc 1991;113:6320. (d) Matsumoto T, Katsuki M, Jona H, Suzuki K. J. Am. Chem. Soc 1991;113:6982.For total syntheses of vineomycinone $B_{2}$ methyl ester, see: Danishefsky S, Uang BJ, Quallich G. J. Am. Chem. Soc 1985;107:1285.

4 (a). (b) Martin SF. Pure Appl. Chem 2003;75:63. (c) Apsel B, Bender JA, Escobar M, Kaelin DE Jr, Lopez OD, Martin SF. Tetrahedron Lett 2003;44:1075. (d) Kaelin DE Jr. Sparks SM, Plake HR, Martin SF. J. Am. Chem. Soc 2003;125:12994. [PubMed: 14570450] (e) Chen C-L, Martin SF. Org. Lett 2004;6:3581. [PubMed: 15387553]For syntheses of C-aryl glycosides based on furanbenzyne cycloadditions, see: Kaelin DE Jr. Lopez OD, Martin SF. J. Am. Chem. Soc 2001;123:6937. [PubMed: 11448205]

5. See also: Hart H, Lai C-Y, Nwokogu GC, Shamouilian S. Tetrahedron 1987;43:5203.

6 (a). Czernecki S, Ville G. J. Org. Chem 1989;54:610. (b) Boyd VA, Drake BE, Sulikowski GA. J. Org. Chem 1993;58:3191.

7. Goldsmith D, Liotta D, Saindane M, Waykole L, Bowen P. Tetrahedron Lett 1983;24:5835.

8. Soderquist JA, Brown HC. J. Org. Chem 1980;45:3571.

9. The enantiomer of 11 is known. See: Corey EJ, Guzman-Perez A, Noe MC. J. Am. Chem. Soc 1995; $117: 10805$.

10 (a). Bock I, Bornowski H, Ranft A, Theis H. Tetrahedron 1990;46:1199.For regioselective brominations, see: Mitchell RH, Lai Y-H, Williams RV. J. Org. Chem 1979;44:4733.

11. Prepared in $35 \%$ yield by silyation of 1.25 eq. 5 (Sigma-Aldrich) with 1.0 eq. TBSCl and imidazole in DMF.

12 (a). (b) Netka J, Crump SL, Rickborn B. J. Org. Chem 1986;51:1189. (c) Camenzind R, Rickborn B. J. Org. Chem 1986;51:1914. The reaction using $\mathrm{KOH}$ in $\mathrm{DMF} / \mathrm{H}_{2} \mathrm{O}(10: 1)$ was more efficient than in DMSO, but use of TBAF gave multiple unidentified products. 

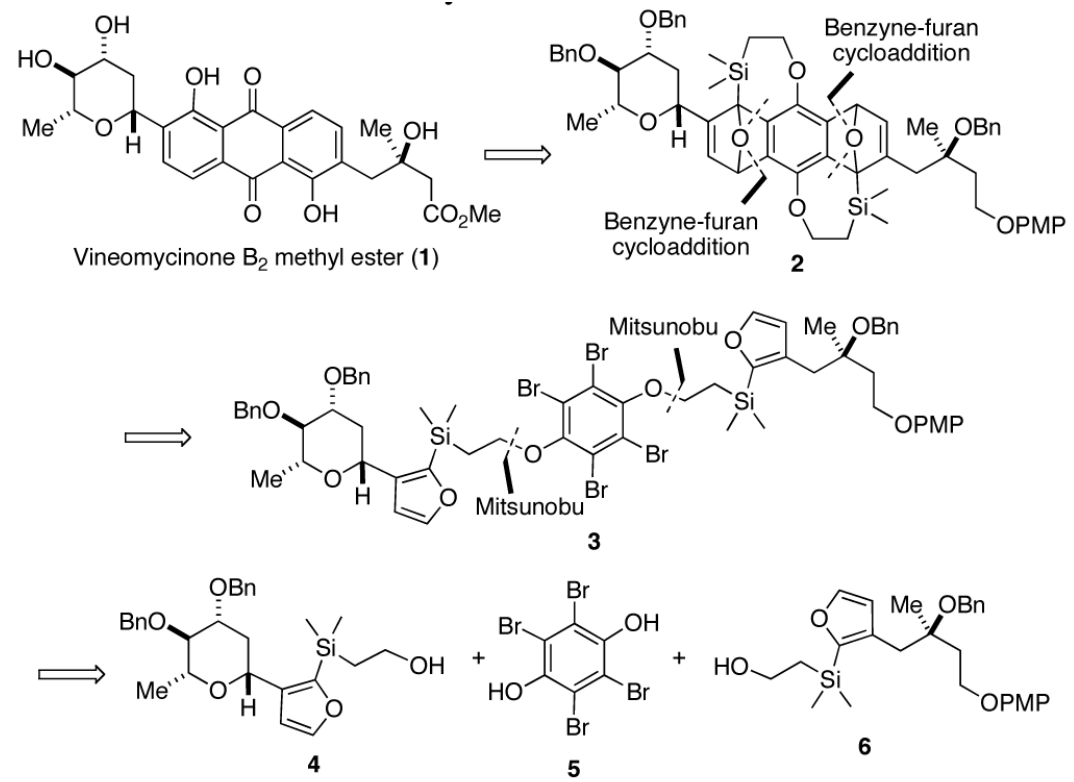

Figure 1.

Retrosynthesis of vineomycinone $\mathrm{B}_{2}$ methyl ester (1) 


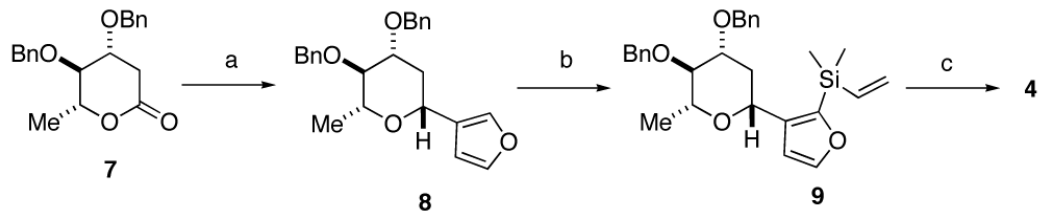

Scheme 1a.

$a$ Reaction conditions: (a) 3-lithiofuran, THF, $-78{ }^{\circ} \mathrm{C}$; $\mathrm{HCl}$, EtOH then $\mathrm{NaCNBH}_{3}, \mathrm{HCl}, 50^{\circ}$ C, $80 \%$; (b) LDA, THF, $-78{ }^{\circ} \mathrm{C}$; $\mathrm{Me}_{2} \mathrm{Si}(\mathrm{Cl}) \mathrm{CH}=\mathrm{CH}_{2}, 70 \%$; (c) 9-BBN, THF; $\mathrm{H}_{2} \mathrm{O}_{2}, \mathrm{NaOH}$, $94 \%$. 


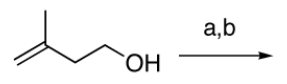

10

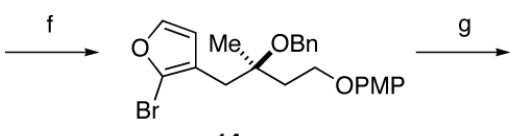

14
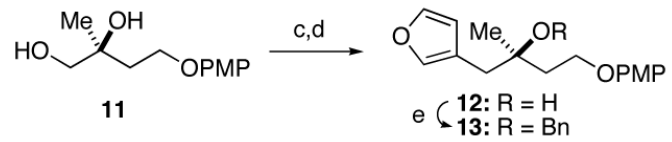

e $\begin{aligned} & \text { 12: } R=H \\ & \text { 13: } R=B n\end{aligned}$

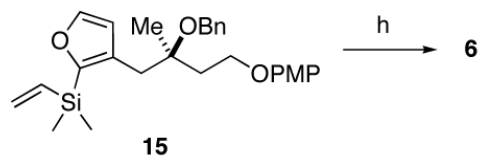

Scheme 2a.

$a$ Reaction conditions: (a) $p$-MeO- $\mathrm{C}_{6} \mathrm{H}_{4} \mathrm{OH}$, DIAD, $\mathrm{PPh}_{3}$, THF, 98\%; (b) AD-Mix $\alpha, \mathrm{H}_{2} \mathrm{O}, t$ $\mathrm{BuOH}, 95 \%$, 96\% ee; (c) TsCl, Et ${ }_{3} \mathrm{~N}$, DMAP, $\mathrm{CH}_{2} \mathrm{Cl}_{2}$; (d) $n$-BuLi, $-78^{\circ} \mathrm{C}$; 3-lithiofuran, $\mathrm{BF}_{3} \cdot \mathrm{OEt}_{2}$, THF, $-78{ }^{\circ} \mathrm{C}, 76 \%$ (2 steps); (e) $\mathrm{KH}, \mathrm{DMF}, 0{ }^{\circ} \mathrm{C} ; \mathrm{BnBr}, 100 \%$; (f) NBS, DMF, $0{ }^{\circ}$ C, $86 \%$; (g) $n$-BuLi, THF, $-78{ }^{\circ} \mathrm{C}$; $\mathrm{Me}_{2} \mathrm{Si}(\mathrm{Cl}) \mathrm{CH}=\mathrm{CH}_{2}, 87 \%$; (h) 9-BBN, THF; $\mathrm{H}_{2} \mathrm{O}_{2}, \mathrm{NaOH}$, $96 \%$. 


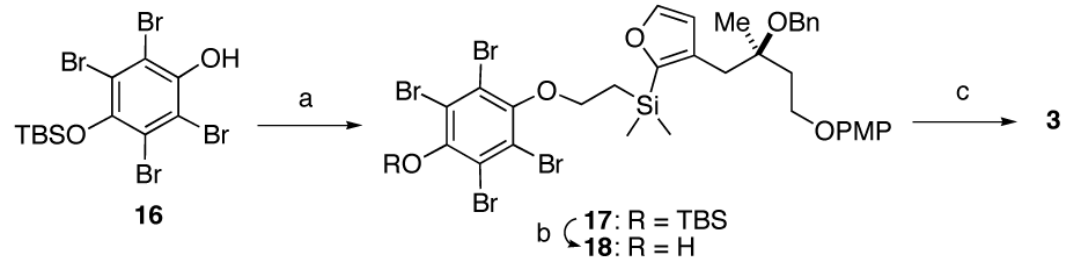

Scheme 3a.

$a$ Reaction conditions: (a) 6, DIAD, $\mathrm{PPh}_{3}$, THF, 75\%; (b) HF.py, THF, $0{ }^{\circ} \mathrm{C}, 85 \%$; (c) 4, DIAD, $\mathrm{PPh}_{3}, \mathrm{THF}, 85 \%$. 

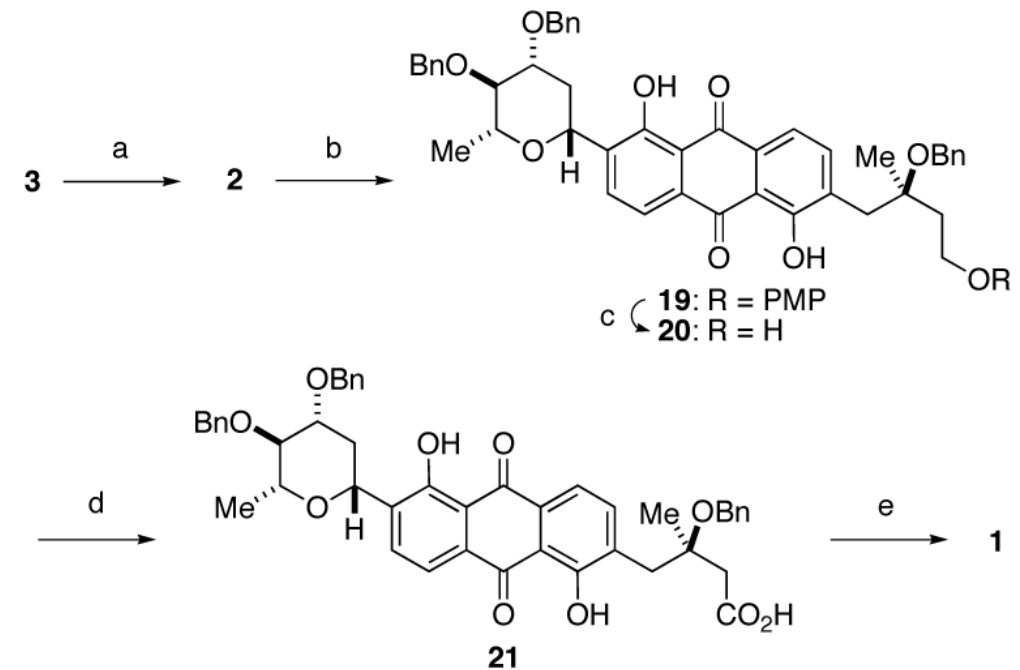

Scheme 4a.

$a$ Reaction conditions: (a) 3.0 eq. $n$-BuLi, ether, $-20^{\circ} \mathrm{C}, 85 \%$; (b) $\mathrm{KOH}, \mathrm{DMF} / \mathrm{H}_{2} \mathrm{O}$ (10:1); $\mathrm{HCl}$, EtOH, $70{ }^{\circ} \mathrm{C}, 34 \%$; (c) $\mathrm{CAN}, \mathrm{CH}_{3} \mathrm{CN}, \mathrm{H}_{2} \mathrm{O},-15{ }^{\circ} \mathrm{C}, 74 \%$; (d) IBX, EtOAc, $80{ }^{\circ} \mathrm{C}$; $\mathrm{NaClO}_{2}, \mathrm{NaH}_{2} \mathrm{PO}_{4}, 2$-methyl-2-butene, $t$-BuOH, $\mathrm{H}_{2} \mathrm{O}, 70 \%$; (e) $\mathrm{BBr}_{3}, \mathrm{CH}_{2} \mathrm{Cl}_{2},-78{ }^{\circ} \mathrm{C}$; $\mathrm{MeOH}, \mathrm{HCl}, \mathrm{rt}, 71 \%$. 